\title{
La organización de los juzgados urbanos: los jueces de paz en su quehacer cotidiano, entre recursos materiales y tramas administrativas (Rosario, 1854-1872)
}

\section{Palabras clave}

administración justicia de paz Rosario siglo XIX

Evangelina De los Ríos*

Fecha de recepción: 23 de mayo de 2020. Fecha de aceptación: 23 de octubre de 2020

\section{Resumen}

El artículo examina el funcionamiento de los juzgados de paz urbanos de la ciudad de Rosario entre 1854 y 1872. Se muestra que estos juzgados tuvieron un papel central en el proceso de reordenamiento político-institucional que buscaba acercar los ámbitos de justicia a la población. En este sentido, el análisis no se ciñe a las orientaciones normativas e institucionales adoptadas por las autoridades del estado sino que atiende, al mismo tiempo, al quehacer cotidiano de los diferentes agentes sociales. Se estudian las tramas administrativas en que se hallaban insertos los jueces de paz y sus comunicaciones con diferentes agentes sociales -jefes de policía, jefes políticos, jueces de primera instancia-, la composición de los juzgados -tenientes y demás auxiliares- y la dinámica y la materialidad en que se desenvolvieron en el ejercicio de sus funciones.

The organization of the urban magistrate courts: the justices of the peace in their daily endeavour, between material resources and administrative plots (Rosario, 1854-1872)

\section{Abstract}

Key-words

administration justice of the peace

Rosario

$19^{\text {th }}$ Century
The paper examines the performance of the urban magistrate courts of the city of Rosario between 1854 and 1872 and shows that these courts have played a key role in the political and institutional reorganization process that sought to bring the areas of justice to the population. In this regard, the analysis in not limited to the regulatory and institutional orientations adopted by the state authorities, but also extends to the daily duties of these judges. This article

\footnotetext{
* Becaria postdoctoral del Investigaciones Socio-Históricas Regionales (ISHR), Centro Científico Tecnológico (CCT) Rosario. Investigadora del Centro de Estudios de Historia Social de la Justicia y Gobierno (CEHISO). Rosario, Santa Fe, Argentina. E-mail: eddelosrios@hotmail.com
} 
studies the administrative plots in which these justices of the peace were involved, their communications with different social agents such as police chiefs, political leaders and first instance judges, the composition of the courts, such as lieutenants and other aid personnel, as well as the dynamic and the materiality which they have developed in the performance of their duties.

\section{Introducción}

A inicios de 1850, los estados provinciales -única entidad estatal que existió por más de tres décadas en el antiguo espacio rioplatense- conformaron un nuevo sistema político en clave nacional, la Confederación Argentina (1852-1861). Este proceso conllevó profundos cambios políticos, económicos y sociales que impactaron a nivel local. ${ }^{1}$ En estos años la ciudad de Rosario jugó un papel central como articuladora del espacio económico-mercantil. Una situación que modificó tanto su fisonomía urbana como su espacio institucional y redefinió el lugar de la justicia de paz.

El objetivo del presente artículo es examinar el funcionamiento de los juzgados de paz urbanos de la ciudad de Rosario entre 1854 y 1872. Un estudio de la baja justicia asentada en los cuarteles de la ciudad requiere una mirada a ras de suelo que tome en cuenta su composición, su materialidad, las tareas que se desarrollaban en estos juzgados y su capacidad para implementar decisiones de gobierno. ${ }^{2}$ La construcción de esta administración se fue tejiendo entre reglamentos, decretos y leyes, pero el proceder de los diferentes agentes sociales -jueces de paz, jefes de policía, jefes políticos, partidas de policía, tenientes alcaldes- delinearon en su ejercicio cotidiano el modo en que desempeñaron estas funciones. Un análisis en términos de quehacer administrativo "puede ser de utilidad para ampliar el conocimiento acerca de la administración pública en tanto práctica política, los agentes que la integraron, y la dinámica y materialidad" (Piazzi y Lanteri, 2019: 242). ${ }^{3}$ Esta investigación, que forma parte de un proyecto más amplio que propone estudiar la configuración de la administración del mundo urbano mediante el análisis micropolítico de los jueces de paz de Rosario, abreva tanto en los aportes provenientes del campo de la Historia social de la justicia (Barriera, 2019: 163-203) como en aquellos estudios que han puesto de relevancia los saberes y las prácticas que acompañaron la conformación de una administración (Bohoslavsky y Soprano, 2010; Plotkin y Zimmermann, 2012) y la reconstrucción de perfiles en los funcionarios (Garavaglia, 2010 y 2012). Cuestiones que han permitido dar cuenta de la complejidad social y política de la administración (Di Liscia y Soprano, 2017).

El artículo se divide en tres apartados: el primero centra la atención en las funciones y las formas en que se organizaban los juzgados de paz urbanos, la comunicación de los jueces de paz con diferentes autoridades locales -jefes políticos, jueces de primera instancia, jefes de policía- y los modos en que se fijaron las cadenas de mando-obediencia. En segundo lugar, se examina el mundo material en el que se desenvolvían estos jueces: ¿en qué lugar despachaban justicia?, ¿cómo estaban dotados estos espacios? y ¿percibían o no remuneración?, constituyen algunas de las preguntas que guían el apartado. Por último, se indaga en los diferentes auxiliares de los juzgados de paz urbanos: alcaldes de barrio, tenientes alcaldes, ayudantes citadores, comisarios de policía y partidas celadoras de la ciudad. Una caracterización de estos funcionarios menores completa el cuadro sobre la administración de justicia. Los jueces no actuaron solos, se hallaban rodeados de una amplia red de agentes
1. La complejidad de este proceso requiere de un examen que excede los límites de este trabajo; por lo tanto, remitimos a los estudios de Garavaglia (2016) y Bragoni y Míguez (2010).

2. Para un análisis sobre la
administración estatal consultar Garavaglia y Pro Ruiz (2013).

3. Para un estudio sobre la materialidad, consultar Piazzi (2017). 
4. Un balance al respecto en Barriera (2019).
5. Sobre la justicia de paz en Santa Fe consúltese Ensinck (1963) y Barriera (2011 y 2014).

6. Para un análisis de este proceso que incluye organigramas sobre la administración de la ciudad de Rosario ver De los Ríos (en prensa)

7. Hacia 1851 Alfred Marbais du Graty, naturalista y geógrafo belga, estimaba que en Rosario habitaban aproximadamente 3.000 personas. Pocos años más tarde, según el censo de la Confederación (1858), la ciudad contaba con al menos 9.587 habitantes. El departamento Rosario era el más poblado de la provincia, contaba con casi el 50\% de la población -unas 22.492 personas. El $42 \%$ vivía en la ciudad de Rosario y el resto en los diferentes distritos de campaña (Santa Fe, Censo de 1858). Para 1869 la población del departamento había alcanzado 47.730 habitantes, 23.169 se hallaban en Rosario y la población restante se distribuía en los dos nuevos núcleos urbanos -San Lorenzo (3.274) y Villa Constitución (1.895)- y los distritos de campaña (19.392). (Argentina, Primer Censo de 1869).

8. Decreto organizando administrativa y judicialmente el pueblo y departamento del Rosario, 30-VII-1854. ROSF, T. II: 213-214. que componían las tramas institucionales que se tornaron más densas de la mano del crecimiento urbano.

En pos de comprender la dinámica del poder político local se emprendieron numerosos trabajos sobre los agentes inferiores de justicia y gobierno -como jueces de paz, comandantes militares, comisarios de campaña, jueces pedáneos, los alcaldes de barrio. ${ }^{4} \mathrm{Su}$ abordaje no sólo requiere de una forma específica de interrogación de las fuentes, también de la ampliación de los reservorios documentales -una cuestión central que permite un examen de la construcción del poder desde la cotidianeidad. En la búsqueda de diferentes materiales la atención se centró en un conjunto de expedientes provenientes del Archivo Histórico Provincial "Dr. Julio Marc" rotulados bajo el título Jueces de paz de ciudad. Se trata de la correspondencia que estos jueces mantenían con las diferentes autoridades locales -jefe político, jefe de policía, juez de primera instancia, comisarios, tenientes alcaldes, etc. A través de estas cartas informaban sobre lo acontecido en el cuartel a su cargo y las formas en que desarrollaban sus actividades; además brindaban explicaciones sobre sus quehaceres y justificaban sus omisiones.

El arco temporal parte de un posicionamiento metodológico que centra la atención tanto en los procesos de cambios institucionales y normativos que transformaron profundamente la justicia de paz, como en el desenvolvimiento relacional de estos jueces dentro del entramado político de esos años. La creación de la jefatura política de Rosario (1854) representó el punto de inflexión de un proceso que acompaña numerosas modificaciones políticas, institucionales y normativas que contribuyeron a redefinir la administración local, la estructura institucional y el diseño judicial en que se movían los jueces de paz, mientras que la reforma de la Constitución provincial (1872) contempló un nuevo régimen de municipalidades mediante el cual la designación de los jueces de paz ya no se efectuaría a instancia del jefe político, sino mediante elecciones a través del voto de los vecinos.

\section{El funcionamiento de los juzgados de paz urbanos}

Durante las décadas de 1830 y 1840, el juez de paz de Rosario, figura instalada desde la supresión del Cabildo (1832), era la máxima cabeza de autoridad del departamento y concentraba amplias atribuciones -judiciales, policiales, comerciales. ${ }^{5}$ Con la elevación de Rosario a ciudad (1852) -un proceso atravesado por fuertes cambios políticos económicos y sociales- fue necesario confeccionar un nuevo armazón político-institucional para gobernar este territorio. ${ }^{6}$ En este contexto de fuerte crecimiento demográfico y urbano, las quejas de los jueces por la sobrecarga de trabajo, las continuas negativas de los vecinos a aceptar los nombramientos y la renuncia de los designados obligaron a las autoridades provinciales a recortar algunas competencias que se encontraban bajo su órbita. ${ }^{7}$

El 30 de julio de 1854 se instituyó una nueva organización política y administrativa para Rosario: la Jefatura Política, y convirtió al Jefe Político en la máxima autoridad del departamento. ${ }^{8} \mathrm{El}$ papel del juez de paz se redefinió, pasaron de uno a cuatro y se transformaron en justicias de menor cuantía al mando de cada uno de los cuarteles en que se dividía la ciudad. Para conocer la forma en que se tejieron las nuevas tramas administrativas se requiere un examen de los circuitos comunicacionales que mantuvieron con las restantes autoridades locales. Si bien una parte importante de esta comunicación era 
verbal, ${ }^{9}$ se conserva un importante conjunto de notas y cartas que permite reconstruir estos tejidos -dando respuesta a ciertas preguntas como a quién se dirigían las cartas, con qué frecuencia, etc.- y las cadenas de mando /obediencia generadas en el ejercicio cotidiano del gobierno de los cuarteles (Molina, 2018).

A partir de la instalación de la Jefatura Política, los jueces de paz quedaron bajo las órdenes del Jefe Político "en cuanto concierne á sus funciones administrativas". ${ }^{10}$ Este último elevaba las ternas para sus nombramientos, proponía su remoción y podía suspenderlos en caso de faltas graves. El Decreto que organizaba administrativa y judicialmente el pueblo y departamento de Rosario (1854) dedica un capítulo -Cap. V- a la forma de elección de los jueces de paz y sus auxiliares, los tenientes alcaldes o tenientes jueces. Estos eran designados anualmente por el gobernador en base a las ternas que el juez de primera instancia elevaba al jefe político para su aprobación. ${ }^{11}$ Aunque no se estipularon cuáles eran los criterios a utilizar ni las condiciones que debían reunir los candidatos, ${ }^{12}$ una y otra vez se reiteraron ciertas fórmulas que resaltaban algunas cualidades como "patriotismo" y "amor al orden". ${ }^{13}$ Pese a lo afirmado en el Decreto, una mirada a la correspondencia entre Jefe Político y jueces de paz revela que era habitual que al juez saliente confeccionara la propuesta ${ }^{14} \mathrm{e}$ incluso, en algunos casos, se permitía recomendar directamente a su sucesor o informar el interés de algún vecino por asumir el cargo. ${ }^{15}$

El Jefe Político ejercía además la vigilancia sobre la conducta pública de los diferentes empleados de la provincia -jefes de policía, jueces de paz, comisarios de sección y de campaña, etc. ${ }^{16}$ En este sentido, actuaba como mediador en los conflictos entre funcionarios de diferentes departamentos. Es interesante observar sus intervenciones en las desavenencias que se suscitaban entre jueces de paz y empleados del departamento de policía. Los jueces apelaron a su autoridad cuando desde la policía se cuestionaba su accionar, ${ }^{17}$ o bien algún comisario liberaba a un preso sin mediar resolución judicial alguna. ${ }^{18}$ Remitían también distintas solicitudes como los pedidos de insumos, el libramiento de sueldos para el personal del juzgado, los nombramientos de citadores, alcaldes y demás personal subalterno. Y dirigieron sus consultas en cuanto a las tareas políticas que tenían encomendadas: presidir las mesas electorales, supervisar el desarrollo de las elecciones, elaborar los padrones y notificar de los comicios a los vecinos de sus cuarteles (Bonaudo, 2005).

Si en cuanto a lo administrativo el juez de paz rendía cuentas ante el Jefe Político, los reglamentos de justicia no dejan de señalar que estos eran "auxiliares de los jueces de $1^{\mathrm{o}}$ Instancia del departamento judicial" ${ }^{19}{ }^{1}$ Desde 1854 , los jueces de paz vieron modificado su lugar en el esquema político, pero también sus competencias judiciales. La instalación de un Juzgado de Primera Instancia en lo civil y criminal redujo su jurisdicción a los cuarteles de la ciudad. Podía oír y sentenciar verbalmente toda demanda por deuda o de otra clase, ejecutar arrestos y prisión por el término de ocho días y conceder apelación. ${ }^{20}$ Su tarea principal era la resolución de orden de la familia y tranquilidad del cuartel "tenían acción, y deber de cortar por vías suaves, cualquiera desatención ruidosa que turbe el orden público en cualquiera hora del día y de la noche, en el distrito de su cuartel y a una cuadra al frente de su morada, o de otro, sino vive en ella el que le corresponde". En caso de no surtir efecto la vía suave, estaban autorizados a hacer uso de la fuerza y decretar el arresto o la prisión, según la gravedad del asunto. Sus sentencias eran apelables en el término de tres días, en caso de apelación debían entregar una boleta para que la parte que se entendiese agraviada la presentara ante el juez de primera instancia en un término no superior a los cinco días. Además, a diferencia de los jueces
9. La correspondencia deja entrever también un cúmulo de comunicación entre las diferentes autoridades locales que escapa a los registros escritos, ya que en las cartas era frecuente que aparecieran expresiones tales como: "como ya le dije personalmente" o "Más tarde pasaré al despacho de VS a imponerlo verbalmente". Jueces de paz de ciudad, Rosario, 15-III-1859. AHPJM, Jefatura política, $1859 \mathrm{C}, \mathrm{n}^{\circ}$ 21, s/f.

10. Ley sobre jurisdicción y atribuciones de la Gejatura Política de Rosario, Rosario, 11-IX-1865. ROSF, T. IV: 427.

11. Decreto organizando administrativa y judicialmente el pueblo y departamento del Rosario, 30-VII-1854. ROSF, T. II: 216 .

12. En los reglamentos de justicia de Santa Fe no se realiza ninguna mención al respecto. Para Buenos Aires se estableció que los jueces de paz debían ser ciudadanos, saber leer y escribir, ser mayores de 25 años, contribuyentes, con residencia de, al menos, dos años en el distrito. (Corva, 2017).

13. Borradores, 28-II-1855. AHPJM, Jefatura Política, $1855 \mathrm{~A}, \mathrm{n}^{\circ} 3$, s/f.

14. Jueces de paz de ciudad, Rosario, 12-I-1863. AHPJM, Jefatura Política, $1863 \mathrm{E}, \mathrm{n}^{\circ} 18$.

15. Jueces de paz de ciudad, Rosario, 12-I-186o. AHPJM, Jefatura política, $1860 \mathrm{D}, \mathrm{n}^{\circ} 29, \mathrm{~s} / \mathrm{f}$

16. Ley sobre jurisdicción y atribuciones de la Gejatura Política de Rosario, Rosario, 11-IX-1865. ROSF, T. IV: 427.

17. Jueces de paz de ciudad, Rosario, 15-XII-1857. AHPJM, Jefatura política, $1857 \mathrm{C}, \mathrm{n}^{\circ} 19, \mathrm{~s} / \mathrm{f}$.

18 Jueces de paz de ciudad, Rosario, 22-I-1862. AHPJM, Jefatura política, $1862 \mathrm{C}, \mathrm{n}^{\circ} 22, \mathrm{~s} / \mathrm{f}$.

19. Reglamento de Justicia, 19-I-1861. ROSF, T. III: 216-217.

20. En un principio los montos de las demandas no podían exceder los 25\$ ni conceder apelación en jurisdicción superior a $6 \$$. Según el nuevo Reglamento de Justica (1861) los jueces de los cuarteles de Rosario y Santa Fe se ocupan en primera instancia de todas las causas civiles de sus respectivas secciones cuyo valor exceda los 30\$ hasta la cantidad de $100 \$$. Los jueces de paz conocerán verbalmente en $1^{\circ}$ instancia de causa civil o mercantil ocurrida en sus respectivos distritos, siempre que la cantidad no exceda de doscientos pesos fuertes, ni sea menor de 50 en la forma establecida en la ley orgánica de los tribunales de 26 de julio de 1864 . Reglamento de Justicia, 19-I-1861. ROSF, T. III: 216-217. Ley organizando el Poder Judicial, 21 de julio de 1864. ROSF, T. IV: $179-180$. 
21. Jueces de paz de ciudad, Rosario, 12-IV-1855. AHPJM, Jefatura política, $1855 \mathrm{D}, \mathrm{n}^{\circ} 19, \mathrm{~s} / \mathrm{f}$.

22. Jefe de policía al Jefe Político, Rosario, 3-I-1858. AHPJM, Jefatura Política, $1858 \mathrm{~A}, \mathrm{n}^{\circ} 13$, s/f.

23. Jueces de paz de ciudad, Rosario, 15-XII-1857. AHPJM, Jefatura política, $1857 \mathrm{C}, \mathrm{n}^{\circ} 19, \mathrm{~s} / \mathrm{f}$.
24. El 18 de marzo de 1855 se dictan las Instrucciones sobre los vagos y malentretenidos y el rol de los comisarios de la campaña y comisarios de distrito. AHPJM, lefatura Política, $1855 \mathrm{~A}, \mathrm{n} \div 3$, s/f. Casi al mismo momento, el 24 marzo de 1855 , se sancionó el Reglamento de policía para el pueblo y departamento de Rosario. AHPJM, Jefatura Política, $1855 A, n \div 3$, s/f. Y el 29 mayo 29 de 1855 se aprueban las Instrucciones que deben servir a los comisarios generales de campaña, interin se sanciona el reglamento general de Policía. AHPJM, Jefatura política, $1855 \mathrm{C}, \mathrm{n}^{\circ} 13$, s/f.

25. Entre estos reglamentos se encuentran: Reglamento de Policía de 1855 (La Confederación, Rosario, 11-XII-1855); Instrucciones de política por los jueces de paz (Documentos varios, Rosario, 24-II1858. AHPJM, Jefatura Política, 1858 $\mathrm{A}, \mathrm{n}^{\circ}$ 9, s/f) y Reglamento de policía para el departamento de Rosario (Documentos Varios, Santa Fe, 20VII-186o. AHPJM, Jefatura Política, $1860 \mathrm{~B}, \mathrm{n}^{\circ} 11$ ).

26. Reglamento de policía, Santa Fe, 9-VIII-1864. ROSF, T. IV: 210.

27. Instrucciones de política por los jueces de paz (Documentos varios, Rosario, 24-II-1858. AHPJM, Jefatura Política, $1858 \mathrm{~A}, \mathrm{n}^{\circ}$ 9, s/f.) de pueblos y colonias, se ocupaban en primera instancia de las demandas criminales sobre injurias y faltas leves -cuyas sentencias podían apelarse ante el juez de primera instancia en lo criminal.

Pese a lo establecido en estos reglamentos de justicia, la documentación revela que los jueces de paz urbanos rendían cuentas al Jefe de Policía, a quien informaban sobre las resoluciones de las conciliaciones, ${ }^{21}$ la remisión de presos, ${ }^{22}$ las sentencias dictadas ${ }^{23}$ y la situación diaria de los cuarteles. Actuaban esperando su aprobación -y no del juez de primera instancia- a quien consultaban e informaban sobre los modos en que administraban justicia. Los sumarios eran enviados primero a la Jefatura de Policía donde se preparaban y -siempre que el jefe político lo considerara apropiado- se presentaban al juzgado, según consta en la nota que precedía a los expedientes (Piazzi, 2014).

Esta subordinación de los jueces de paz a la Jefatura de Policía fue denunciada por la prensa de la época: "No hay hoy juez que haya prestado ciega obediencia a los mandatos de policía" (Echegoyen, 1859). Una situación que despertó fuertes polémicas. Acusaron al departamento de policía de asumir funciones judiciales y someter a estos funcionarios menores del poder judicial. A través de una solicitada publicada en el diario El Litoral se relatan estos abusos:

¡Causa asombro! Ver en una sociedad culta tanta humillación, tanta degradación por parte de estos jueces de paz -de esos funcionarios públicosque no son comisarios de policía ni de sesión por tan solo aquel artículo del reglamento expresado- sino miembros del poder judicial, y que como tales miembros de este poder, de suyo resultaría la odiosa incompatibilidad de ser a la vez comisarios de policía; si en un país en que hay separación de poder, como principio esencial de las libertades constitucionales y del sistema republicano, y en que a ningún miembros de esos poderes les es dado proceder jamás, sin cometer atentado, contra la esencia misma del sistema, donde solo imperan las leyes que castigan las arbitrariedades, por que los excesos de autoridad deben tener reparación (Echegoyen, 1859).

Más allá de los tópicos estatalistas que remarcaban la creación de un sistema republicano basado en la separación de poderes, tal y como lo contemplan las constituciones nacional y provincial, los relatos de los jueces y los reclamos en la prensa revelan que en la práctica las tramas entre los poderes locales continuaban superpuestas a tal punto que la injerencia policial en las causas judiciales terminaron por subordinar a los jueces de paz a los mandatos policiales.

Al mismo tiempo, esta subordinación a la policía era una consecuencia de las tareas policiales que cumplían los jueces de paz cuya esfera de acción se formuló mediante resoluciones elaboradas a nivel local. ${ }^{24}$ Los diferentes reglamentos de policía sancionados a lo largo de estos años dejaron en manos de estos jueces -y no de los comisarios de sección- la tarea de hacer cumplir las ordenanzas..$^{25}$ Los jueces de paz fueron considerados como "la policía correccional en la ciudad" ${ }^{26}$ Se diagramaron diversas funciones de las que debían ocuparse como: evitar peleas y juegos de azar; prohibir el uso de palabras obscenas, blasfemias, cualquier cosa que ofenda "la moral, decencia y buenas costumbres de la sociedad"; controlar el comercio -venta, extracción, etc.- de animales y cueros sin certificación; supervisar que diferentes comercios no vendieran material robado o bebidas al mostrador. Fueron autorizados a ejecutar edictos policiales, aplicar multas y realizar las certificaciones. ${ }^{27}$ También cumplieron con otras funciones de policía, en el sentido antiguo del término: se ocuparon del aseo, la limpieza y la iluminación de las calles y la recaudación 
de ciertos impuestos. Estuvieron a cargo de la elaboración de los registros de la contribución directa y de las patentes de negocios, la entrega de marcas y guías, el control de pesos y medidas, y la realización de los primeros registros estadísticos. ${ }^{28}$ Los motivos no eran sólo descriptivos sino también fiscales, ya que la necesidad de sancionar nuevos impuestos requería de la recolección de datos precisos (De los Ríos, 2017a).

\section{El ordenamiento administrativo de los juzgados de paz: horarios, calendarios y recursos}

Los juzgados de paz y la conformación de una administración en oficinas

Desde el plano discursivo el proceso de conformación de una administración debía ser acompañado de la creación de un universo de oficinas (Veira, [1815] 2000). Su construcción generaba una nueva dinámica que garantizaba la convergencia de las actividades administrativas por parte de los empleados estatales, pero también representó una imagen simbólica del Estado través de la asistencia diaria y la confección de rutinas y horarios. En Rosario, por ejemplo, se invirtieron cuantiosos recursos para la construcción del edificio de la Jefatura Política, edificio que compartió con el Juzgado de Primera Instancia. ${ }^{29}$ Sin embargo, estas dependencias carecían de los mínimos recursos materiales. Como ha mostrado Carolina Piazzi, el juzgado se ubicaba en una pequeña habitación que funcionaba con grave perjuicio de la administración de justicia "por ser la única habitación que le está destinada, la cual se encuentra diariamente llena de las personas que concurren en demandas verbales instruyéndose de asuntos tan delicados como los que se ventilan ante este Juzgado" ${ }^{30}$ Las oficinas de hacienda padecían idénticos inconvenientes. La Receptoría del departamento Rosario se hallaba en el mismo local donde funcionaba la Capitanía del Puerto y la Comandancia del Resguardo. Su ubicación fue una enorme ventaja en aquellos momentos en que los receptores estuvieron a cargo -al mismo tiempo- de la administración de la Aduana. Sin embargo, hacia 1853 cuando la aduana pasó a jurisdicción nacional los problemas estuvieron a la orden del día. El receptor Pedro Lassaga se quejaba ante el Colector Gral. sosteniendo que: "estando todo el archivo que me dejó el administrador saliente D. Frías en una pieza donde entran y salen 18 o 20 guardas no sería extraño la pérdida de algunos papeles, pues ya me he sucedido". ${ }^{31}$ Estas dificultades contribuyeron a repensar su ubicación y finalmente se aprobó su traslado al edificio de la Jefatura Política. ${ }^{32}$

La construcción de una administración en oficinas oculta un universo de indefiniciones en los niveles más capilares del tejido social. Los juzgados de paz urbanos funcionaron en las casas particulares de los jueces y los tenientes alcaldes. Una condición fundamental en los nombramientos era que residieran en el cuartel. Cualquier designación que recayera en una persona por fuera de la sección, o bien una vez nombrado se mudara, constituía un motivo de cese inmediato. En el mismo sentido, algunos vecinos propuestos para el cargo se negaron a aceptar argumentando que permanecían mucho tiempo fuera de casa y, por lo tanto, "el juzgado se hallaría siempre en acefalia". ${ }^{33}$ No sólo era importante vivir en el cuartel, también se tomó en cuenta la ubicación de su residencia. Algunos jueces de paz rehusaron ciertas candidaturas para tenientes alcaldes que enviaba el Jefe Político y propusieron otras afirmando: "Este nombramiento lo he hecho porque se hacía sentir la necesidad de otro alcalde en esta sección que estuviera más céntrico pues el primero que había mandado se encontraba un poco a trasmano".$^{34}$ La medida tenía como fin preservar el
28. Jefatura política, Rosario, 14-X1854. AHPJM, Jefatura política, T. Único, $\mathrm{n}^{\circ} 12$, s/f.

29. Para solventar el proyecto, las autoridades provinciales autorizaron la venta de un número importante de tierras fiscales. Rosario, 17-VIII-1866. ROSF, T. V: 179.

30. Nota del juez Ovier al Tribunal de Alzada. AGPSF, Gobierno, T. 15, 1856, f. 606 (en Piazzi, 2012: 196).

31. Notas del receptor de Hacienda de Rosario al Contador General de la provincia, Rosario, 8-XI-1854. AGPSF, Contaduría, T. 97, Leg. 39, s/f.

32. Para un examen de las condiciones materiales de las oficinas de hacienda consúltese De los Rios (2017).

33. Jueces de paz de ciudad, Rosario, 11-IV-1862. AHPJM, Jefatura Política, $1862 \mathrm{C}, \mathrm{n}^{\circ} 22, \mathrm{~s} / \mathrm{f}$.

34. Jueces de paz de ciudad, Rosario, 3-X-1862. AHPJM, Jefatura Política, $1862 \mathrm{C}, \mathrm{n}^{\circ} 22, \mathrm{~s} / \mathrm{f}$. 
35. También para los nombramientos de los comisarios de distrito en la campaña se buscaron individuos que residieran en el centro del distrito. Un análisis con más en detalle en De los Ríos y Piazzi (2012).

36. La proximidad no refiere únicamente a la cercanía geográfica, aunque a primera vista esta aparece como más real y objetiva, sino a otros elementos como: las distancias material, simbólica, procesal, social y administrativa. Véase Barriera (2012a y 2012b).

37. Decreto fijando las horas de despacho al Juez de $1^{\circ}$ instancia de la Capital y al Juez de Paz del departamento del Rosario. Santa Fe, 21-XII-1852. ROSF, T. II: 126.

38. Jefatura de policía, Rosario, 27VII-1855. AHPJM, Jefatura política, ${ }_{1855} \mathrm{C}, \mathrm{n}^{\circ} 15, \mathrm{~s} / \mathrm{f}$.

39. Sanción legislativa estableciendo un derecho a la arena que se introduzca al Rosario, y cuyo producto deberá invertirse en el pago del reloj público de esa ciudad. Santa Fe, 22-IX-1857. ROSF, T. II: 378.

40. Decreto fijando las horas que deben abrirse los Tribunales y oficinas públicas. Santa Fe, 17-X-1856. ROSF, T. II: 352. orden de todo el cuartel, ya que residir en un punto extremo de la jurisdicción podía ser perjudicial para el desempeño de sus funciones. ${ }^{35}$ La tarea de estos auxiliares era central ya que, como afirma Garavaglia, "ejercían una mediación o una aproximación 'más capilar' sobre la población local" (Garavaglia, 1999: 99). Por lo tanto, la baja justicia, que representaba los escalones más bajos de la administración, constituía una verdadera justicia de proximidad y se esperaba que se hallara cercana respecto a la comunidad sobre la que debía actuar. ${ }^{36}$

\section{La conformación de las rutinas administrativas}

Hacia la segunda mitad del siglo XIX, las autoridades provinciales dictaron una serie de decretos en pos de estructurar ciertas prácticas administrativas vinculadas con la regulación de horarios, calendarios, etc. Un decreto del 21 de diciembre de 1852, sancionado por el entonces gobernador D. Crespo, fijó los horarios de funcionamiento de la administración de justicia: tanto el Juzgado de Primera Instancia como el Juzgado de Paz de Rosario debían abrir por la mañana desde las ocho y media hasta las doce y "desde las oraciones hasta las ocho de la noche" siendo esta segunda hora destinada a atender exclusivamente las demandas verbales y causas criminales urgentes. ${ }^{37}$ Además se buscó regular los horarios en que funcionaban las dependencias policiales: se dispuesto su apertura desde las diez de la mañana hasta las dos de la tarde y desde las siete de la tarde "hasta el toque de ánimas". Igualmente, un comisario de servicio actuaba desde las siete de la tarde hasta el día siguiente a fin de garantizar la permanencia de un funcionario para entender en los casos en los que fuera necesaria la cooperación pública. ${ }^{38}$ En este sentido, la constitución de un tiempo público fue una parte importante del proceso de formación del Estado y algo esencial para el funcionamiento de la administración (Bourdieu, 2012: 22). Aunque se invirtieron ingentes recursos provinciales para la compra de relojes públicos, que debían ubicarse en lugares estratégicos de los diferentes municipios, ${ }^{39}$ continuó rigiendo el horario religioso y las campanadas de la iglesia marcaban la marcha de la administración. Un signo de una sociedad que continuaba manteniendo formas de sociabilidad propias del Antiguo Régimen.

Para 1856 un decreto del gobernador Juan Pablo López estableció que las oficinas públicas estaban obligadas a funcionar, al menos, cuatro horas diarias: en primavera y verano tenían que permanecer abiertas desde las nueve a las trece horas, mientras que en otoño e invierno el horario se retrasaba una hora, de diez a catorce horas. Las únicas dependencias que contaban con una jornada más amplia eran las de policía, supeditadas a cualquier eventualidad y con guardia nocturna en caso de considerarse oportuno. ${ }^{40}$ Las disposiciones fueron cumplidas sólo en parte: los jueces de paz y tenientes alcaldes debían atender cualquier conflicto que se sucediera en el cuartel en cualquier momento del día.

La organización del tiempo era importante para el cumplimiento de un calendario administrativo: los jueces estaban obligados a pasar cada quince días las planillas donde constaban las multas cobradas y a remitir el dinero a la caja del departamento de Policía, remisiones que ingresaban bajo el concepto de eventuales. Debían informar en tiempo y forma los plazos para el pago de impuestos, los vencimientos de los pagarés y las deudas y el cumplimiento de distintos ordenamientos -entrega de armas, elecciones, conformación de las guardias nacionales, etc. También, según los reglamentos de justicia, presentaban mensualmente una relación de las causas al Juzgado de Primera Instancia. Además se encargaban del cumplimiento de los plazos judiciales, por ejemplo, aquellos que mantuvieran una demanda ante el juzgado sólo tenían entre tres y cinco días para presentar apelaciones. Para informar a los 
vecinos del cuartel sobre estos términos, los horarios y los costos de las multas por infracciones, los jueces de paz fijaron en la puerta del juzgado un cartel donde exhibieron los reglamentos de policía. Dicho cartel debía permanecer a plena vista durante todo el día y ser guardado durante la noche. ${ }^{41}$

\section{Algunos aspectos de la materialidad de los juzgados de paz urbanos}

Comprender el quehacer cotidiano de los juzgados de paz requiere una mirada sobre sus recursos materiales. La información volcada en los inventarios brinda un panorama sobre las condiciones en que se desenvolvían los jueces de paz. La correspondencia que circulaba entre las diferentes dependencias crea lo que Antonio Hespanha (1989) llamó memoria administrativa, que plasma en papel no sólo su accionar sino que, al mismo tiempo, revela aspectos de su materialidad. El juez de paz entregaba el archivo a su sucesor, quien comunicaba haber recibido todo en tiempo y forma. ${ }^{42}$ Los inventarios que presentaban las autoridades salientes y las notas de las entrantes muestran la precariedad de estas dependencias. En la mayoría de los casos, solo constaban algunos libros de actas, libretas y unas pocas armas -sable o tercerola- que se utilizaban para el personal del juzgado. ${ }^{43}$ En el inventario del cuartel $n^{\circ} 4$, el nuevo Juez de Paz, José Cepeda, informa que recibió: " 5 notas instrucciones pertenecientes a dicho juzgado. El escudo del juzgado. El reglamento de policía. 3 tercerolas incluida una en mal estado. 4 sables de tropa incluso una sin vaina. 2 escopetas en buen estado, con tiros de tropa". ${ }^{44}$ Estas carencias materiales se traducían en quejas ante las dificultades de armar a los tenientes alcaldes, armamentos sin los cuales no podían ejercer sus funciones. ${ }^{45} \mathrm{Si}$, como señala Yangilevich (2017: 88), establecer el buen orden estaba estrechamente vinculado con la posibilidad de armar al personal subalterno, resulta complejo pensar que los juzgados funcionaran de forma correcta sin contar con recursos materiales para ello.

Las dificultades de conseguir de forma regular papel sellado, certificados, tinta para escribir -incluso la carencia de copias de los reglamentos- estuvieron a la orden del día y entorpecieron el funcionamiento de la administración de los juzgados. Así en su nombramiento el nuevo juez de paz, José Ma. Fernández, afirmaba:

me apersone al señor Juan Sousa para que me pusiera en posesión del archivo y demás útiles concerniente al juzgado y por todo he recibido todo unas lanza que con impropiedad deberá usarse en la ciudad en casos necesarios, libros, decretos, circulares de ninguna clase, no hay ni reglamento, causa papel ninguno correspondiente al archivo del juzgado.

La situación relatada por los jueces no es ajena al contexto general de la administración provincial que carecía de los insumos básicos para su funcionamiento.

\section{Los salarios de los jueces de paz: debates y propuestas}

La justicia de paz establecida a partir del Reglamento de Justicia de 1833 marcó diferencias en los sueldos de los jueces. Mientras en los departamentos de Rosario y San Gerónimo percibieron salario, cumplieron sus funciones ad honorem en el de San José y también los jueces de los cuarteles de la ciudad de Santa Fe (Barriera, 2011). Este mismo reglamento estipulaba un sueldo de $100 \$$ anuales para el de Rosario -que fue reajustado a lo largo de los años siguientes alcanzando los $300 \$$ anuales para $1852^{47}$ y duplicándose a $600 \$$ anuales en $1854-{ }^{48}$ pero la situación cambió con la creación de la Jefatura política. Su conversión en justicia de menor cuantía revistió a los nombramientos con
41. Jueces de paz de ciudad, Rosario, 14-XII-1854. AHPJM, Jefatura política, T. Único, $\mathrm{n}^{\circ} 16$, s/f.

42. Jueces de paz de ciudad, Rosario, 27-IV-1855. AHPJM, Jefatura política, $1855 \mathrm{D}, \mathrm{n}^{\circ} 19, \mathrm{~S} / \mathrm{f}$.

43. Jueces de paz de ciudad, Rosario, 2-IV-1862. AHPJM, Jefatura política, $1862 \mathrm{C}, \mathrm{n}^{\circ} 22, \mathrm{~s} / \mathrm{f}$.

44. Jueces de paz de ciudad, Rosario, 15-I-1859. AHPJM, Jefatura política, $1859 \mathrm{C}, \mathrm{n}^{\circ} 21, \mathrm{~s} / \mathrm{f}$.

45. Jueces de paz de ciudad, Rosario, 1-V-1858. AHPJM, Jefatura Política, $1858 \mathrm{C}, \mathrm{n}^{\circ} 18, \mathrm{~s} / \mathrm{f}$.

46. Jueces de paz de ciudad, Rosario, 13-II-1856. AHPJM, Jefatura política, $1856 \mathrm{C}, \mathrm{n}^{\circ} 23, \mathrm{~s} / \mathrm{f}$.

47. En marzo de 1852 la Legislatura provincial resolvió aumentar los sueldos de los empleados públicos de la provincia considerando que: "es una economía mal entendida y ofende el decoro de toda buena administración, el establecimiento de sueldos que no proporcione a los empleados públicos una subsistencia cómoda y decente". El incremento del sueldo mantuvo las diferencias entre los jueces de paz de los diferentes departamentos: el de Rosario pasó a cobrar 300\$ anuales, mientras que los de San Gerónimo y San José cobraron apenas 10o\$s. ALP, Cámara de Diputados, T. 1, fs. 49-50.

48. Sanción Legislativa asignando sueldo al juez de Paz y al Juez de Policía del Rosario, 18-I-1854. ROSF, T. II: 191. 
49. Reglamento de Justicia, 19-I-1861, artículo 32. ROSF, T. III: 216-217.

50. Instrucciones de política por los jueces de paz (Documentos varios, Rosario, 24-II-1858. AHPJM, Jefatura Política, $1858 \mathrm{~A}, \mathrm{n}^{\circ}$ 9).

51. Los gastos en policía y, en menor medida, justicia representaron dos de los principales rubros de egresos. El departamento de policía fue el que más recursos recibió: más de un $25 \%$ de los ingresos se destinaron a su sostenimiento, mientras que cerca del $12 \%$ se empleó en la administración de justicia (De los Ríos, 2017b).

52. Decreto dividiendo en tres cuarteles La Capital y en cuatro la ciudad del Rosario. Santa Fe, 12-XII1869. ROSF, T. VI: 76. carácter de carga pública, ad honorem. Sin embargo, el Reglamento de Justicia (1861) decretó que en las ciudades de Santa Fe y Rosario se les entregara como emolumento la cantidad de $4 \$$ por cada una de las causas que conocieren en primera instancia, debiendo en caso de sentencia pagarlos la parte condenada, y en caso de avenimiento o transacción por mitades. ${ }^{49} \mathrm{Al}$ mismo tiempo, como los presupuestos provinciales tampoco contemplaron ningún estipendio para el funcionamiento de los juzgados de paz de la ciudad, se creyó justo que la mitad de lo producido por el cobro de multas y sellos, la recaudación de algunos impuestos o el pago de las contravenciones se destine a gastos de escritorio y gratificaciones a las personas que ocupaban el servicio del juzgado -los citadores, como se verá más adelante. ${ }^{50}$

Las autoridades provinciales fueron cuidadosas al nombrar para estos puestos a personas que gozaban de una buena posición económica. Aunque se requiere un estudio exhaustivo para tener una imagen más nítida de su perfil social, un primer acercamiento nos revela que estos fueron, en general, personas influyentes en lo local y con experiencia en el manejo de asuntos económicos. Eran casi en su totalidad comerciantes, tenderos y negociantes; es decir, personas que contaban con recursos para solventar su existencia sin necesidad de sueldo, por lo que el puesto -lejos de constituir una forma de conseguir ingresos estables- representaba una carga pública que algunas veces resultaba ingrata. La situación no era muy distinta en los juzgados de paz rurales: los jueces de paz de las colonias y los pueblos de campaña percibían un salario pero sus magros estipendios, sumado a las dificultades en su percepción, obligaron a destinar en estos puestos a personas que contaran con algún otro sustento que respaldara sus actividades. Muchos eran comerciantes y pulperos, lo que ocasionó múltiples dificultades en el ejercicio de sus tareas.

Entre 1856 y 1863, la administración de justicia dobló sus partidas presupuestarias como consecuencia de la creación de nuevas instituciones: la Exma. Cámara de Justicia, la separación de los Juzgados de Primera Instancia en lo Civil y en lo Criminal y el establecimiento de nuevos juzgados de paz en la campaña santafesina. ${ }^{51}$ En este sentido, se comenzó a considerar la necesidad de otorgar salarios a los jueces de paz de los cuarteles de la ciudad. A mediados de 1860, luego de un intenso debate, se acordó finalmente el pago de un estipendio. Se trató de una medida esencial en el diseño de una arquitectura propiamente estatal basada en una administración más cercana a la visión clásica de una burocracia rentada. Sin embargo, la asignación de sueldos se acompañó de otras medidas como el reordenamiento en el diseño de la plana urbana. El Decreto afirmaba que: “considerando que el $\mathrm{n}^{\circ}$ de jueces de paz que actualmente existen en esta capital y ciudad de Rosario, sin facilitar la administración de justicia en la parte que a ellos está encomendada, produciría un recargo de gastos de consideración sin ninguna ventaja para la administración"..$^{5}$ Así Santa Fe quedó dividida en tres cuarteles -ya no cuatro- mientras Rosario pasó de seis a cuatro al tiempo que se multiplicó la presencia de la baja justicia, la más cercana a la población, mediante el nombramiento de dos tenientes de jueces en cada cuartel. Por lo tanto, los juzgados de paz de Rosario quedaron integrados por cuatro jueces y ocho tenientes jueces.

Si observamos el Cuadro 1 es posible notar que el salario de los jueces de paz urbanos fue inferior al establecido para los rurales, cuestión vinculada a la diferencia en sus funciones. Como se ha señalado ya, en los pueblos y colonias de la campaña, los jueces de paz representaban la máxima autoridad local. Ahora bien, si comparamos el sueldo de un juez de paz urbano es claro que se encontraba muy por debajo de lo que ganaba, por ejemplo, un comisario de 
sección. Esto ameritaría un estudio exhaustivo, pero una primera aproximación al tema señala que los comisarios de sección fueron en general vecinos que no contaban con otras ocupaciones, se trataba de individuos provenientes de sectores muy bajos de la sociedad que no contaban con otros ingresos más que los reportados por el desempeño de su oficio en el departamento de policía.

\begin{tabular}{|c|c|c|c|}
\hline & Juzgados de Paz & $\begin{array}{l}\text { Sueldo } \\
\text { mensual }\end{array}$ & $\begin{array}{c}\text { Sueldo } \\
\text { anual }\end{array}$ \\
\hline \multirow[t]{3}{*}{$1868 *$} & $\begin{array}{l}\text { Rosario (4), ciudad de Santa Fe (3), San Lorenzo, Villa Consti- } \\
\text { tución, Calchines, San José, Sauce, Esperanza y Coronda }\end{array}$ & $50 \$ \$ F$ & $600 \$ \mathrm{~F}$ \\
\hline & Colonias de San Gerónimo, San Carlos, Helvecia y Sunchales & $30 \$ \mathrm{~F}$ & $360 \$ F$ \\
\hline & Escribientes (12) & $12 \$ \mathrm{~F}(\mathrm{c} / \mathrm{u})$ & $144 \$ F$ \\
\hline \multirow[t]{4}{*}{1869} & $\begin{array}{l}\text { Rosario (4), Ciudad de Santa Fe (3), San José, Santa Rosa, San } \\
\text { Gerónimo, Helvecia, Sauce, Coronda }\end{array}$ & $30 \$ \mathrm{~F}(\mathrm{c} / \mathrm{u})$ & $360 \$ F$ \\
\hline & Tenientes de La Capital (3) y Rosario (4) & $20 \$ \mathrm{~F}(\mathrm{c} / \mathrm{u})$ & $240 \$ F$ \\
\hline & $\begin{array}{l}\text { Esperanza, San Carlos, San Lorenzo, Villa Constitución, San } \\
\text { José de la Esquina }\end{array}$ & $50 \$ \mathrm{~F}(\mathrm{c} / \mathrm{u})$ & $600 \$ \mathrm{~F}$ \\
\hline & $\begin{array}{l}\text { Escribientes para San Carlos, Esperanza, San Lorenzo, Villa } \\
\text { Constitución, San José de la Esquina }\end{array}$ & $12 \$ \mathrm{~F}(\mathrm{c} / \mathrm{u})$ & $144 \$ F$ \\
\hline \multirow[t]{4}{*}{1870} & $\begin{array}{l}\text { Rosario (4), Ciudad de Santa Fe (3), San Gerónimo, Helvecia, } \\
\text { Cayastá, Sauce, Emilia, San Justo, Cayastacito, San Javier, } \\
\text { Colonia California, Francesa }\end{array}$ & $30 \$ \mathrm{~F}(\mathrm{c} / \mathrm{u})$ & $360 \$ \mathrm{~F}$ \\
\hline & Tenientes de La Capital (3), Rosario (4) & $20 \$ \mathrm{~F}(\mathrm{c} / \mathrm{u})$ & $240 \$ \mathrm{~F}$ \\
\hline & $\begin{array}{l}\text { Coronda, San José, Esperanza, San Carlos, San Lorenzo, Villa } \\
\text { Constitución y San José de la Esquina }\end{array}$ & $50 \$ \mathrm{~F}(\mathrm{c} / \mathrm{u})$ & $600 \$ F$ \\
\hline & Escribientes (11) & $12 \$ \mathrm{~F}(\mathrm{c} / \mathrm{u})$ & $144 \$ F$ \\
\hline \multirow[t]{7}{*}{1872} & Rosario (4) Ciudad de Santa Fe (2), Helvecia, Candelaria, & $40 \$ \mathrm{~F}(\mathrm{c} / \mathrm{u})$ & $480 \$ \mathrm{~F}$ \\
\hline & $\begin{array}{l}\text { Tenientes juez Santa Fe (2), Teniente juez de Rosario (4), } \\
\text { Teniente juez de San Lorenzo, Teniente Juez de Villa Consti- } \\
\text { tución, Juez de paz de Sunchales }\end{array}$ & $25 \$ \mathrm{~F}(\mathrm{c} / \mathrm{u})$ & $300 \$ \mathrm{~F}$ \\
\hline & Esperanza, San Carlos, San Lorenzo, Villa Constitución & $50 \$ \mathrm{~F}$ & $600 \$ \mathrm{~F}$ \\
\hline & $\begin{array}{l}\text { San Justo, Cayastá, Emilia, Humboldt, Sauce, Cayastacito, } \\
\text { San Gerónimo, San José de la Esquina, Bertrand, Jesús María }\end{array}$ & $30 \$ F$ & $360 \$ F$ \\
\hline & $\begin{array}{l}\text { San Javier, Teniente de juez de San Gerónimo, de Esperanza } \\
\text { (2) y San Carlos (2) }\end{array}$ & $20 \$ F$ & $240 \$ F$ \\
\hline & $\begin{array}{l}\text { Escribientes para los juzgados de Esperanza, San Carlos, } \\
\text { Emilia, San Gerónimo, Helvecia, San Justo, San Lorenzo, Villa } \\
\text { Constitución, San José de la Esquina }\end{array}$ & $12 \$ \mathrm{~F}(\mathrm{c} / \mathrm{u})$ & $144 \$ F$ \\
\hline & Gastos extraordinarios por cada juez de paz de campaña & & $3 \$ \mathrm{~F}(\mathrm{c} / \mathrm{u})$ \\
\hline
\end{tabular}

*Para 1868 no se sancionó presupuesto, un decretó estableció la vigencia del presupuesto del año anterior.

Fuentes: Elaboración propia en base Presupuesto de Santa Fe 1867, ROSF, T. 6: 232-247; Presupuesto de Santa Fe 1869, ROSF, T. 6: 332-346; Presupuesto de Santa Fe 1870, ROSF, T. 7: 25- 40 y Presupuesto de Santa Fe 1872, ROSF: T. 7: 313-330.

Cuadro 1. Partidas presupuestarias para los juzgados de paz (1868-1872). 


\begin{tabular}{|l|r|r|r|r|}
\hline Cargo & $\mathbf{1 8 6 8}$ & $\mathbf{1 8 6 9}$ & $\mathbf{1 8 7 0}$ & $\mathbf{1 8 7 2}$ \\
\hline Gobernador & 4.800 & 4.800 & 4.800 & 4.800 \\
\hline Jefe político de Rosario & 2.400 & 2.400 & 2.400 & 2.400 \\
\hline Defensor de Pobres y menores & 600 & 960 & 960 & 960 \\
\hline Juez en lo civil de Rosario & 2.160 & 2.180 & 2.280 & 2.400 \\
\hline Comisario de Orden & 660 & 600 & 600 & 720 \\
\hline Juez de paz de Rosario & 600 & 360 & 360 & 480 \\
\hline Teniente de la compañía de Gendarmes & 360 & 360 & 360 & 360 \\
\hline Comisario de sección & 600 & 600 & 600 & 600 \\
\hline
\end{tabular}

*Para 1868 no se sancionó presupuesto, un decretó estableció la vigencia del presupuesto del año anterior.

Fuentes: Elaboración propia en base al Presupuesto de Santa Fe 1867, ROSF, T. 6: 232-247; Presupuesto de Santa Fe 1869, ROSF, T. 6: 332-346; Presupuesto de Santa Fe 1870, ROSF, T. 7: 25- 40; Presupuesto de Santa Fe 1872, ROSF: T. 7: 313-330.

Cuadro 2. Comparativo de sueldos anales (en pesos fuertes).

\section{Los "recursos humanos" de los juzgados de paz urbanos}

Los auxiliares de los jueces de paz ¿tenientes alcaldes, tenientes jueces o alcaldes de barrio?

Las fuentes no permiten una reconstrucción completa del perfil social del personal que componía los juzgados de paz, ya que no contamos con todos los nombramientos para la elaboración de una serie como la confeccionada por Garavaglia (1999) para la campaña de Buenos Aires. No obstante, la documentación interna del juzgado integrada por la correspondencia que enviaban los jueces de paz a las autoridades superiores -jefe político o jefe de policía- permite una mirada a ras de suelo sobre estos tenientes. Eran los propios jueces quienes relataban a sus superiores a través de escritos sobre su accionar cotidiano. En estos legajos figuran pocas cartas de puño y letra de los tenientes alcaldes o los jueces, quienes sólo de forma excepcional se dirigían en forma escrita -por ejemplo, en caso de aceptación o renuncia de su cargo- a los jueces de paz o al Jefe Político. Las órdenes que emanaban del juzgado se trasmitían de forma verbal. Estos se presentaban cada día a la casa del juez, quien comunicaba sus quehaceres u ordenaba los pasos a seguir frente a demandas, conflictos o cualquier otra situación a dirimir en el cuartel.

Los auxiliares eran designados por el Jefe Político a partir de la propuesta elevada por el juez de paz. Al igual que los jueces, no se hallaban estipulados los criterios para su elección, pero se pretendía nombrar individuos

53. Jueces de paz de ciudad, Rosario, 12-I-1860. AHPJM, Jefatura política, $1860 \mathrm{D}, \mathrm{n}^{\circ} 29, \mathrm{~s} / \mathrm{f}$
54. Jueces de paz de ciudad, Rosario, 12-III-1861. AHPJM, Jefatura política, $1861 \mathrm{~B}, \mathrm{n}^{\circ} 17, \mathrm{~s} / \mathrm{f}$. que reunieran dos condiciones centrales: "capacidad y patriotismo"..$^{53}$ Una vez recibida la comunicación que lo designaba y aceptado el puesto debía dirigirse a la jefatura, para ser anotado en el registro y prestar juramento. Quienes rehusaban la nominación estaban obligados a elevar una nota al Jefe Político del departamento, explicando los motivos de su renuncia. En estos casos, los argumentos utilizados eran numerosos: "estar próximos a salir de la ciudad", tener problemas de salud, demasiadas ocupaciones o bien expresiones menos descriptivas como estar impedido por "motivos personales". ${ }^{54}$ Es preciso recordar que estos puestos no gozaban de sueldo alguno, por lo tanto los candidatos debían estar dispuestos a dejar de lado sus negocios u ocupaciones, una decisión nada sencilla. Las continuas renuncias llevaron a 
que los jueces de paz optaran por consultar primero a los elegidos antes de elevar la propuesta y así tener garantizada la aceptación del nombramiento. ${ }^{55}$

La presencia de estos auxiliares era esencial para el funcionamiento del juzgado, los jueces de paz incluyeron esta petición como condición para asumir sus funciones. Así, en la notificación al jefe político del departamento, Mariano Alvarado, el juez de paz de la 2da sección, Cecilio Domínguez afirma:

\begin{abstract}
$\mathrm{Al}$ aceptar este puesto me permito rogar a vs se sirva poner en conocimiento del exmo gobierno, que haré cuanto de mi dependa para seguir mereciendo la confianza con que se me honra. Así mismo permítame VS elevar al conocimiento del exmo gobierno por conducto de vs las necesidades de que adolece este juzgado para poner hacer el servicio con alguna regularidad. La larga acefalia en que ha estado este juzgado, ha dejado la plaza de alcaldes vacante en esta virtud me permito proponer para desempeñar estos puestos a los ss José Dilis y D. Fructuoso Martinez, personas ambas de reconocida probidad y honradez y que por esta razón merece el aprecio general. ${ }^{56}$
\end{abstract}

Al mismo tiempo, algunos jueces amenazaban con renunciar debido a que: “No habiendo recibido contestación ninguna me permito hacer presente a SS que me sería imposible continuar desempeñando este puesto sin que se me provea de un teniente juez". ${ }^{57}$

Ahora bien, ¿quiénes eran estos auxiliares de los jueces de paz? Durante la primera mitad del siglo XIX, los únicos auxiliares con los que contaba el juez de paz de Rosario eran los comisarios de cuartel. El Reglamento de Justicia de 1833 estableció dos comisarios para la villa y los "que se consideraran necesarios para la campaña". Poco tiempo después, de la mano del crecimiento demográfico y de la expansión de la plana urbana, los comisarios pasaron a cuatro, uno por cada cuartel. ${ }^{58}$ Las funciones que cumplían eran análogas a las desempeñadas por los jueces de paz de los cuarteles de la ciudad de Santa Fe. Por lo tanto, no se limitaban a desempeñar tareas policiales sino que estaban autorizados a oír y sentenciar verbalmente en toda clase de demanda hasta la cantidad de $25 \$$ y a resolver cualquier controversia vinculada al orden de la familia y la tranquilidad del cuartel. También podía ejecutar con arresto o prisión por el término de ocho días y conceder apelación superior a la cantidad de $6 \$ .^{59}$

Como se ha señalado ya, el Decreto de Organización Administrativa y Judicial de Rosario (1854) modificó la baja justicia nombrando cuatro jueces de paz para los cuarteles de la ciudad, cada uno con su respectivo teniente alcalde. Dicho decreto que desglosa las tareas, las competencias y las formas de elección de las diferentes autoridades locales -jefe político, juez de primera instancia, jefe de Policía, etc.- se limita a señalar que los jueces y tenientes alcaldes "tendrán las atribuciones designadas a los de su clase por el Reglamento de Justicia". ${ }^{60}$ Es decir, deja a los jueces de paz de la ciudad las ocupaciones que cumplían hasta entonces los comisarios de cuartel o, dicho de mejor manera, los comisarios de cuartel perdieron entonces sus competencias judiciales ahora en manos de los jueces de paz. Tal es así que los primeros jueces de paz nombrados fueron: "los ciudadanos que actualmente sirven como comisarios de cuartel, D. Cayetano Carbonell, D. Emilio Maldonado, D. Pedro Ramírez y D. Romualdo Bravo" ${ }^{61}$ Esta situación obligó a las autoridades provinciales a designar nuevos comisarios para ocupar estas funciones, aunque no fueron cuatro como hasta entonces sino solo dos.
55. Jueces de paz de ciudad, Rosario, 4-XII-1862. AHPJM, Jefatura Política, $1862 \mathrm{C}, \mathrm{n}^{\circ} 22, \mathrm{~s} / \mathrm{f}$.

56. Jueces de paz de ciudad, Rosario, 17-X-1863. AHPJM, Jefatura Política, $1863 \mathrm{E}, \mathrm{n}^{\circ} 18$, s/f.

57. Jueces de paz de ciudad, Rosario, 29-X-1863. AHPJM, Jefatura Política, $1863 \mathrm{E}, \mathrm{n}^{\circ} 18$, s/f.

58. Decreto nombrando varios empleados. Santa Fe, 28-XII-1852. ROSF, T. II: 132.

59. Reglamento provisorio para los empleados y atribuciones que debe subrogar al Cuerpo municipal, extinguido por ley de 13 de octubre de 1832, Santa Fe, 28-I-1833. ROSF, T. I: 245-247.

6o. Decreto organizando administrativa y judicialmente el pueblo y departamento del Rosario, 30-VIII-1854. ROSF, T. II: 215 .

61. Decreto nombrando Juez de 1ra. Instancia en lo civil y criminal y Jueces de Paz para la ciudad y departamento del Rosario. Santa Fe, 14-VIII-1854. ROSF, T. II: 217. 
62. Jueces de paz de ciudad, Rosario, 20-II-1858. AHPJM, Jefatura Política, $1858 \mathrm{C}, \mathrm{n}^{\circ} 18, \mathrm{~s} / \mathrm{f}$.

63. Decreto nombrando Juez de 1ra. Instancia en lo civil y criminal y Jueces de Paz para la ciudad y departamento del Rosario. Santa Fe, 14-VIII-1854. ROSF, T. II: 217.

64. Estos auxiliares fueron nombrados como alcaldes de cuartel en 1854 y 1860 . Mientras que en 1861 y 1863 se denominaron teniente de juez. En los restantes años figuraron como tenientes alcaldes.

65. Reglamento de Justicia, 19-I-1861. ROSF, T. III: 216-217.

66. Ley organizando la Administración de justicia, 21-V-1863. ROSF, T. IV: 40 .

67. Santa Fe, enero 19 de 1853 . ALP, Cámara de Diputados, T. 1, f. 259.

68. Santa Fe, enero 22 de 1853. ALP, Cámara de Diputados, T. 1, fs. 25253.
Darío Barriera afirma que a partir de la creación del Reglamento de justicia de 1833 las funciones que cumplían los antiguos alcaldes de barrio pasaron a manos de los jueces de paz de los cuarteles de la ciudad en el caso de la ciudad de Santa Fe -y a los comisarios de cuartel en Rosario, devenidos en jueces de paz en la segunda mitad del siglo XIX-. Es decir, que los alcaldes de barrio fueron reemplazados por jueces de paz como justicias de proximidad (Barriera, 2018). Es interesante notar que este cambio nominal ha sido más rápido en la legislación que en la conciencia de los actores sociales. Así Eudoro Carrasco, juez de paz del cuartel $n^{\circ} 1$, firmaba sus cartas al jefe político bajo el título de alcalde. Todavía en 1858, ante una demanda llevada adelante por el juez de paz del cuartel $n^{\circ} 4$, Nicolás Ma. Álvarez, el representante del demandado, Valentín Ricardo, acusa al juez de excederse en su sentencia y sostiene que apelará el dictamen y pondrá

en conocimiento de la superioridad la arbitrariedad de este juzgado al tomarse la facultad de extender actas, pues que no había tales juzgados de paz, que solo eran unos simples jueces de barrio, y que el gobierno sin saber les daban el nombre de jueces de paz. ${ }^{62}$

El uso del concepto "jueces de barrio" es interesante ya que marca una distancia entre quienes consideraban que podían administrar justicia y quienes desempeñaban tareas menores, de segundo orden, y sólo debían limitarse a arreglos verbales o de conciliación.

Siguiendo estos lineamientos no es extraño que los auxiliares de los jueces de paz recibieran el título de tenientes alcaldes. Para 1854 el decreto de nombramiento de los jueces de paz urbanos para Rosario estipuló que fueran ellos mismos quienes "propusieran al gobierno a los tenientes alcaldes para cada cuartel" ${ }^{63} \mathrm{~A}$ lo largo de estos años, estos auxiliares recibieron numerosas denominaciones: tenientes alcaldes, teniente jueces y, en algunos años también, alcaldes de barrio. ${ }^{64}$ En el nuevo Reglamento de Justicia (1861) los alcaldes de barrio aparecen en el escalón más bajo del esquema judicial y se los menciona como "auxiliares del juez de paz de la sección á que pertenezcan, para el desempeño de sus funciones". ${ }^{65}$ Sin embargo, con la aprobación de un nuevo esquema para la organización de la administración de justicia (1863) ya no se los menciona, en su lugar se nombran a los tenientes jueces como auxiliares de los jueces de paz para las ciudades de Rosario y Santa Fe. ${ }^{66}$

¿Cuáles eran las funciones de estos auxiliares? Su creación en Santa Fe como parte de la baja administración de justicia de la ciudad data de finales de la década de 1840. Como no figuraban ni en el Reglamento de Justicia (1833) ni en la Constitución Provincial (1849) y dada la insistencia del Juez de primera Instancia, quien escribía al ministro de gobierno para trasmitirle las preocupaciones de los jueces de paz que desconocían cuáles eran las funciones de los tenientes alcaldes, la Legislatura provincial sancionó un decreto para deslindar su jurisdicción. ${ }^{67}$ Se creó entonces una comisión con el objetivo de fijar la esfera de atribuciones de estos tenientes y así "evitar la anarquía en que se haya la administración inferior de justicia" ${ }^{68} \mathrm{El}$ decreto consta de cuatro artículos que demarcaban sus competencias. En primer lugar, los tenientes de los jueces de paz entendían y definían demandas hasta la suma de $5 \$$. Estos podían oír y juzgar en todo asunto que evite desordenes o escándalos en sus cuarteles. En segundo lugar, cortaban por vías suaves "cualesquiera desavenencias ruidosas o que turbe el orden público en cualquier hora del día o de la noche en el distrito de su cuartel". Para ello estaban facultados para hacer uso de la fuerza pública, en caso de ser necesario. Podían valerse de la colaboración de 
los vecinos de su dependencia o con las partidas de policía para proceder a un arresto o enviar a prisión a un delincuente, dando cuenta al juez de paz de su cuartel. Por último, se los nombró como reemplazantes naturales de los jueces, en caso de enfermedad, ausencia, muerte o impedimento legal. ${ }^{69}$ En el nuevo Reglamento de Justicia (1861) los tenientes jueces no aparecen mencionados y quienes figuran en el escalón más bajo del esquema judicial son los alcaldes de barrio como "auxiliares del juez de paz de la sección á que pertenezcan, para el desempeño de sus funciones" . ${ }^{70}$ Estos cambios no modificaron sus injerencias, pero si los montos de las demandas sobre las que podían entender: estos debían conocer en lo civil y de forma verbal todas las causas de sus respectivas secciones que no excedieran los 30\$, y en caso de apelación elevarlas ante el juez de paz, quien conocía estas causas en segunda y última instancia (Barriera, 2017). Un año más tarde, un nuevo decreto sobre el Poder Judicial modificó las competencias de los jueces de paz, pero no la de los tenientes jueces -ya no alcaldes de barrio- que continuaron atendiendo en demandas menores a $30 \$$. Para ello debían llevar un cuaderno donde asentaban las transacciones, avenimientos, conciliaciones y sentencias -decisiones que podían ser apeladas ante los jueces de paz de su respectivo cuartel. ${ }^{71}$ En la década de 1870, los montos en las causas se modificaron alcanzando la cantidad de $50 \$ \mathrm{~F}^{72}$

Los estudios realizados para Buenos Aires han mostrado que los alcaldes y los tenientes alcaldes eran oficiales civiles a quienes no correspondían en caso alguno juzgar, pero cuyas atribuciones eran celar el cumplimiento de las leyes y contribuir con todos los recursos de sus cuarteles a mantener el orden y observar las disposiciones del departamento de policía (Garavaglia, 1999). Como marca Sofía Gastellu (2018: 273), Bernardino Rivadavia “calificó de trascendental la diferencia entre jueces de paz y alcaldes de barrio, ya que los primeros eran magistrados que debían influir en la paz doméstica mientras que los segundos -en tanto oficiales civiles- no podían juzgar". En Santa Fe, en cambio, estos auxiliares eran oficiales judiciales y tenían como tarea principal administrar justicia (Barriera, 2017). Existe una segunda diferencia entre ambos casos: en Buenos Aires los alcaldes de barrio estaban supeditados tanto a la autoridad de los jueces de paz como de los jefes de policía (Gastellu, 2019). En Rosario, estos auxiliares dependían directamente de los jueces a quienes rendían cuentas y sólo en aquellos casos en los que por diversos motivos -ausencia, prisión o impedimento del juez- quedaban a cargo del juzgado, dirigían su comunicación hacia la Jefatura de Policía. ${ }^{73}$

Los tenientes jueces o tenientes alcaldes representaron el escalón más bajo de la administración de justicia urbana. Las cartas de los jueces de paz resultan especialmente reveladoras al respecto. Veamos dos ejemplos: el 4 de diciembre de 1862, Ramón Casas, juez de paz de la 2da sección de la ciudad, escribe al secretario de la jefatura política, Samuel Navarro, afirmando:

El infrascrito tiene noticia de que no existe en esta sección el teniente alcalde que por la ley de la provincia debe ser nombrado en cada cuartel o sección, para atender en las demandas cuyo valor no exedan de 30 pesos. Esta falta noto que perjudica mucho a la gente pobre del pueblo que necesita del juez competente que dirima sus controversias. ${ }^{74}$

La declaración del juez de paz era taxativa: la acefalía del puesto perjudicaba a los vecinos que no tenían a quién recurrir en busca de justicia, ya que aquellas pequeñas causas estaban fuera de la jurisdicción de los jueces de paz. Luego de recibida la nota e informado el Jefe Político, resuelve de forma inmediata solicitarle al Juez una propuesta para cubrir la vacante. ${ }^{75}$
69. Santa Fe, enero 28 de 1853 . ALP, Cámara de Diputados, T. 1, f. 503.

70. Reglamento de Justicia, 19-I-1861. ROSF, T. III: 216-217.

71. Ley organizando el Poder Judicial, 21-VII-1864. ROSF, T. IV: 179-180.

72. Ley referente a causas civiles que deben conocer los Jueces de paz, Santa Fe 21 de septiembre de 1871. ROSF, T. VII: 310.

73. Jueces de paz de ciudad, Rosario, 13-IV-1859. AHPJM, Jefatura Política, $1859 \mathrm{C}, \mathrm{n}^{\circ} 21, \mathrm{~s} / \mathrm{f}$.

74. Jueces de paz de ciudad, Rosario, 4-XII-1862. AHPJM, Jefatura Política, $1862 \mathrm{C}, \mathrm{n}^{\circ} 22, \mathrm{~s} / \mathrm{f}$.

75. Jueces de paz de ciudad, Rosario, 22-XII-1862. AHPJM, Jefatura Política, $1862 \mathrm{C}, \mathrm{n}^{\circ} 22$, s/f. 
76. Jueces de paz de ciudad, Rosario, 29-X-1863. AHPJM, Jefatura Política, $1863 \mathrm{E}, \mathrm{n}^{\circ} 18$, s/f.

77. Jueces de paz de ciudad, Rosario, 10-XII-1854. AHPJM, Jefatura política, T. Único, $n^{\circ} 16$, s/f.

78. Jueces de paz de ciudad, Rosario, 11-IV-1859. AHPJM, Jefatura política, $1859 \mathrm{C}, \mathrm{n}^{\circ} 21, \mathrm{~s} / \mathrm{f}$.

79. Jueces de paz de ciudad, Rosario, 28-VI-1859. AHPJM, Jefatura política, $1859 \mathrm{C}, \mathrm{n}^{\circ} 21, \mathrm{~s} / \mathrm{f}$.

8o. Jueces de paz de ciudad, Rosario, 16-VII-1859. AHPJM, Jefatura política, $1859 \mathrm{C}, \mathrm{n}^{\circ} 21, \mathrm{~s} / \mathrm{f}$.

81. Jueces de paz de ciudad, Rosario, 28-VI-1858. AHPJM, Jefatura Política, $1858 \mathrm{C}, \mathrm{n}^{\circ} 18, \mathrm{~s} / \mathrm{f}$.

82. Jueces de paz de ciudad, Rosario, 8-II-1859. AHPJM, Jefatura política, $1859 \mathrm{C}, \mathrm{n}^{\circ} 21, \mathrm{~s} / \mathrm{f}$.

83. Reglamento provisorio para los empleados y atribuciones que debe subrogar al Cuerpo municipal, extinguido por ley de 13 de octubre de 1832, Santa Fe, 28-I-1833. ROSF, T. I: 245-247.

84. Así el juez de paz de la 1ra sección, Juan Belmudez, escribe al jefe de policía, Coronel José A. Fernández, solicitando que: “El que tiene espera de VS servirá proporcionar un vigilante armado que precisa hoy en este juzgado para llenar con más exactitud un deber de los que debe cumplir". Jueces de paz de ciudad, Rosario, 23XII-1857. AHPJM, Jefatura Política, $1857 \mathrm{C}, \mathrm{n}^{\circ} 19, \mathrm{~s} / \mathrm{f}$.

85. Jueces de paz de ciudad, Rosario, 12-III-1859. AHPJM, Jefatura Política, $1859 \mathrm{C}, \mathrm{n}^{\circ} 21, \mathrm{~s} / \mathrm{f}$.
Un segundo ejemplo lo constituye la carta del juez de paz de la 3ra sección, José Antonio Machado, al Jefe político del departamento:

se dirigió este juzgado una nota a SS en la que demostraba la urgente necesidad de que se proveyera a este juzgado de un teniente juez, para lo cual me había permitido indicar la persona del ciudadano D. José Díaz. No habiendo recibido contestación ninguna me permito hacer presente a SS que me sería imposible continuar desempeñando este puesto sin que se me provea de un teniente juez.

Muchas e innumerables son las quejas que a cada paso presentan los ciudadanos, y las mayores de ellas de muy poca importancia y que pertenecen a los tenientes por cuya razón no pueden ser atendidas e interrumpen a cada paso el despacho de este juzgado. Espero que ss en vista a la urgente necesidad tomará una medida que salve en lo posible el inconveniente que tiene este juzgado para funcionar" ${ }^{76}$

La nota deja entrever dos cuestiones centrales: en primer lugar, ante la falta de un auxiliar, las amenazas de los jueces de paz de renunciar al cargo estuvieron a la orden del día. En estos casos, las autoridades locales actuaron con premura y aceptaron las propuestas elevadas por los jueces. En segundo lugar, esta situación no sólo afectó la administración de la baja justicia sino que provocó todo tipo de inconvenientes en el funcionamiento del juzgado. Estos auxiliares cumplían funciones muy importantes: se encargaban de la remisión de presos, ${ }^{77}$ el cobro de multas, ${ }^{78}$ la persecución de vagos y malentretenidos, ${ }^{79}$ el relevamiento de notas, la confección de inventarios de embargo, deudas y demás. ${ }^{80}$ Además informaban sobre lo ocurrido en el cuartel y en casos de delitos o infracciones reunían las pruebas y entrevistaban a testigos y/o partícipes. ${ }^{81}$ Solicitaron la colaboración de vigilantes en caso de no ser obedecido en las citaciones o para proceder a los arrestos. ${ }^{82}$ En este sentido, mantuvieron estrechas relaciones con el departamento de policía, aunque en ningún aspecto rendían cuentas al Jefe de Policía.

\section{Los otros auxiliares del juzgado: partidas de policía y ayudantes citadores}

Además de los tenientes alcaldes o tenientes jueces, los jueces de paz contaron con la colaboración de las partidas de policía de la ciudad. El Reglamento de Justicia de 1833 estableció en su artículo 9ำ que en caso de ser necesario debía hacer "uso de la fuerza con los vecinos de su dependencia o con la partida celadora, quienes los deberán auxiliar" ${ }^{\prime 3}$ Su colaboración era esencial en casos de fuga o persecución de un reo, situación que exigía el recorrido de grandes distancias o incluso el traslado a la campaña para lo cual se requerían recursos -caballos, armas, oficiales.

Los pedidos elevados por los jueces de paz al jefe de policía por vigilantes para el desempeño de tareas de los juzgados -arrestos, entrega de citaciones, requerimientos de algún demandado, etc.- eran casi diarios. ${ }^{84}$ Las citaciones por demandas o los arrestos no siempre eran bien recibidos y no faltaron episodios de violencia que motivaron a muchos jueces a pretender estar siempre acompañados por alguna autoridad policial. Estos presionaban fuertemente al jefe de policía para que enviara a algún vigilante para el servicio del juzgado, quienes cumplieron la función de dependientes del juzgado. Así el Juez de paz, Policarpo López, escribía al jefe de policía comunicándole que debía citar a los ciudadanos de su cuartel para la elección de diputados y no teniendo un auxiliar: "se sirva ordenar se ponga a disposición de este juzgado de vigilantes que para ello es muy necesario". ${ }^{85}$ Los ejemplos al respecto son más que 
numerosos: para citar a los vecinos del cuartel para componer el Tribunal de Comercio, el Juez de paz del cuartel n³, Pedro Ramírez, pide: "se sirva poner a su disposición un asistente por proceder al acto de la citación" ${ }^{86}$

La colaboración entre juzgado y jefatura de policía no siempre era armoniosa. Los jueces presentaron quejas al Jefe Político por la negativa de los Jefes de Policía de enviar soldados a cubrir las tareas del juzgado. El juez de paz de la $4^{\mathrm{o}}$ sección, Nicolás Ma. Álvarez, reclamó el envío de un auxiliar porque un demandado se presentó a su juzgado profiriendo todo tipo de insultos y se quejó ante el Jefe Político porque no consiguió arrestarlo: "por no haber estado presente el soldado, no lo remite preso a ese departamento". ${ }^{87}$ En contrapartida, desde la propia jefatura de policía las quejas sobre la insuficiencia de vigilantes para atender asuntos vinculados a la custodia de la ciudad y la prevención de los delitos por la falta de soldados eran constantes. Por lo tanto, se mostraban reticentes a enviar oficiales a cubrir tareas más cercanas a lo administrativo porque sostenían que distraía al personal de sus obligaciones más importantes, como eran el mantenimiento del orden y la vigilancia del departamento.

Para remediar esta situación los jueces de paz se vieron obligados a valerse de otros ayudantes que desempeñaran funciones en los juzgados. Así, por ejemplo, cuando el juez de paz Romualdo Bravo asumió el juzgado de la $4^{\underline{o}}$ sección afirmaba:

\begin{abstract}
hace tres días a que se halla en esta y hoy de la fechas ha recibido un oficio del oficial primero de la policía y para el cumplimiento de ello pidió un asistente que hace tiempo que se ordenó se le diese para el servicio de este cuartel $\mathrm{n}^{\circ}$ 4 desde esa fecha hasta hoy se ha servido de sus criados para asistentes y no ha exigido le fuese dado por la policía, cuando hoy por el oficial 1ro de policía le fue contestado que conchavase un peón si precisa, que el no había de salir a buscar. ${ }^{88}$
\end{abstract}

Como describe la nota de Bravo, los jueces utilizaron sus propios criados para enviar documentos o citaciones o bien conchabaron a peones para cumplir con las obligaciones más urgentes. Los continuos reclamos por asistentes para desempeñar todas aquellas tareas administrativas demandaron la creación de un nuevo puesto: el ayudante citador. Este oficial tuvo varias particularidades: por un lado, el jefe político autorizó estos nombramientos en algunos años a petición directa de los jueces de paz que amenazaban con presentar su renuncia por la falta de auxiliares. Por el otro lado, es interesante notar que, si bien estos puestos se crearon de manera informal, los citadores gozaron de un sueldo de $8 \$$ mensuales -prerrogativa que los diferenciaba de jueces y tenientes cuyas funciones eran ad honorem. Como este salario no se hallaba contemplado en el presupuesto provincial, se debía cubrir con el pago que se realizaba por cada citación -cada citador percibía dos reales por cada citación. ${ }^{89}$ En aquellas ocasiones en que no conseguían reunir dinero suficiente para pagar la totalidad del sueldo, se recurrió a la caja de la policía que contaba con las sumas pertenecientes a los denominados eventuales. ${ }^{90}$ Los citadores además del sueldo percibían racionamiento, se les entregaba armamento y también un vestuario completo. Un detalle no menor, ya que la distinción de su autoridad a través de la portación de un vestuario era un aspecto esencial para el reconocimiento de su autoridad pública.

Su tarea no se limitó a la entrega de citaciones, cumplían con el traslado de notas, cartas y demás papeles entre las diferentes oficinas de la ciudad. Debían
86. Jueces de paz de ciudad, Rosario, 2-IX-1854. AHPJM, Jefatura política, T. Único, $n^{\circ} 19$, s/f.

87. Jueces de paz de ciudad, Rosario, 16-V-1858. AHPJM, Jefatura Política, $1858 \mathrm{C}, \mathrm{n}^{\circ} 18, \mathrm{~s} / \mathrm{f}$.

88. Jueces de paz de ciudad, Rosario, 12-II-1855. AHPJM, Jefatura política, $1855 \mathrm{D}, \mathrm{n}^{\circ} 19, \mathrm{~s} / \mathrm{f}$.

89. Jueces de paz de ciudad, Rosario, 12-X-1857. AHPJM, Jefatura política, $1857 \mathrm{C}, \mathrm{n}^{\circ} 19, \mathrm{~s} / \mathrm{f}$.

90. Jueces de paz de ciudad, Rosario, 11-XII-1857. AHPJM, Jefatura política, $1857 \mathrm{C}, \mathrm{n}^{\circ} 19, \mathrm{~s} / \mathrm{f}$. 
91. Jueces de paz de ciudad, Rosario, 21-X-1857. AHPJM, Jefatura política, $1857 \mathrm{C}, \mathrm{n}^{\circ} 19, \mathrm{~s} / \mathrm{f}$.

2. Jueces de paz de ciudad, Rosario, 30-XI-1857. AHPJM, Jefatura política, $1857 \mathrm{C}, \mathrm{n}^{\circ} 19, \mathrm{~s} / \mathrm{f}$. notificar a los vecinos de las órdenes emanadas desde el juzgado -como aquellas vinculadas al mantenimiento del orden, recolección de basura, cuidado de la calle, corte de árboles, arreglo de veredas, construcción de tapiales, etc. ${ }^{91}$ También se encargaban de notificar los vencimientos y los plazos para el pago de impuestos. Llevaban el dinero recaudado en el juzgado por multas, eventuales de policía o causas iniciadas en el juzgado, que debía rendirse en la caja de la jefatura para que el jefe de policía reuniera los fondos y diera cuenta de ello al receptor de hacienda del departamento (De los Ríos, 2017b).

El puesto de citador representaba un riesgo, ya que a menudo eran golpeados por los vecinos que se negaban a aceptar la citación, muchos incluso fueron apuñalados en el cumplimiento de sus funciones. El 30 noviembre de $1857 \mathrm{el}$ Juez de paz de la $4^{\circ}$ sección, Nicolás María Álvarez, citó a Enrique Paz por una demanda que pesaba en su contra por el robo de un caballo. Luego de que se lo sentenciara a entregar el caballo y a pagar las costas del proceso, Paz amenazó al Juez afirmando que "tenía mucha plata para hacerme pagar la injusticia le que había hecho" y se retiró del juzgado. Ante esta situación de desobediencia, el juez relataba en su carta al Jefe de Policía: "En el acto mandé llamar al citador y le ordené lo presentase a este juzgado y habiéndole dado la orden de presentarse dijo que no venía y en seguida tomo un facón y le tiró dos estocadas al mismo citador, y enseguida se encerró en un cuarto con llave". ${ }^{92}$ Situaciones de violencia como las descriptas estuvieron a la orden día.

\section{Conclusión}

El estudio de esta justicia de menor cuantía urbana constituye un mirador desde el cual se puede observar la lenta conformación de la arquitectura estatal (Barriera, 2016). La narrativa sobre el proceso de construcción del estado del siglo XIX, que resalta la conformación de poderes divididos, la construcción de una administración en oficinas, la especialización de saberes y la profesionalización de sus funcionarios, oculta -muchas veces- un universo de indefiniciones en los niveles más capilares del tejido social. Atender a la dinámica de funcionamiento institucional y al ejercicio de los agentes desde los quehaceres cotidianos permite observar estos procesos a ras de suelo.

Una mirada en la correspondencia evidencia la distancia entre la letra de los reglamentos y el accionar cotidiano de la administración. La correspondencia de los jueces de paz con distintas autoridades locales, que permite reconstruir los canales de comunicación y las cadenas de mando-obediencia, revela que la mentada separación de poderes era todavía muy incipiente. Las cartas dejan ver que rendían cuentas de sus tareas judiciales ante el Jefe de policía y no ante el Juez de Primera Instancia, a quien sólo ocasionalmente dirigían alguna notificación. Para comprender estos flujos comunicacionales entre las diferentes autoridades es preciso recordar que las tareas de los jueces no se agotaban en lo judicial. Los jueces continuaron desempeñando -además de sus funciones judiciales- tareas policiales, políticas y fiscales y la imposición de un orden constitucionalista y republicano parece todavía difusa. La creación de una jefatura de policía y la conformación del Juzgado de Primera Instancia no significó el deslinde de las funciones de policía y justicia. Tanto los jueces de paz en la ciudad como los comisarios de distrito en la campaña encarnaban la tradicional indivisión de atribuciones. La concentración de funciones muestra hasta qué punto las imbricaciones entre justicia y policía pervivieron hasta avanzada la segunda mitad del siglo XIX. 
Los juzgados de paz, lejos de constituirse en un espacio separado de oficina, continuaron funcionando en las casas particulares de los jueces y sus tenientes. El nombramiento de vecinos que residieran en el centro de cuartel evidencia que la cercanía se consideraba central. Representaron una verdadera justicia de proximidad donde la ubicación de estos juzgados era de vital importancia para garantizar que la población de los cuarteles hallara espacios de administración de justicia donde dirimir sus conflictos menores, sin necesidad de hacer uso de la justicia de primera instancia. Al mismo tiempo, la multiplicación de auxiliares -tenientes alcaldes, tenientes jueces o alcaldes de barrio-, quienes representaban el escalón más bajo de la administración de justicia, deja entrever que la necesidad de aumentar presencia era una respuesta al importante número de usuarios que utilizaron estos canales para resolver controversias en los niveles más bajos de la sociedad. 


\section{Q Abreviaturas}

"Archivo de la Legislatura Provincial (ALP)

»Archivo General de la Provincia de Santa Fe (AGPSF)

" Archivo Histórico Provincial “Dr. Julio Marc” (AHPJM)

»Registro Oficial de la Provincia de Santa Fe (ROSF) 


\section{Q Bibliografía}

Argentina ([1869] 1872). Primer Censo Nacional de la República Argentina, 1869, Buenos Aires, Imprenta El Porvenir.

" Barriera, D. (2011). “Rediseñando lo judicial, reinventando lo jurídico: el reglamento de 1833 y los orígenes de la justicia de paz en la provincia de Santa Fe" en Ayrolo, V. (coord.); Actas de las IV Jornadas de Trabajo y Discusión sobre el siglo XIX Las Provincias en la Nación: 213-226. Mar del Plata. CEHiS/ FH-UNMDP, CB ediciones.

» Barriera, D. (2012a). Justicia de proximidad: pasado y presente, entre la historia y el derecho. PolHis, Revista Bibliográfica del Programa Interuniversitario de Historia Política 5/10 (2): 50-57.

》 Barriera, D. (2012b). Instituciones, justicias de proximidad y derecho local en un contexto reformista: designación y regulación de jueces de campo en Santa Fe (Gobernación Intendencia de Buenos Aires) a fines del siglo XVIII. Revista de Historia del Derecho 44: 1-28.

" Barriera, D. (2014). "La dimensión política de un acontecimiento jurídico. Tras los orígenes de justicia de paz en la provincia de Santa Fe (1833)" en Sierra, M.; Pro, J. y D. Mauro (eds.); Desde la historia. Homenaje a Marta Bonaudo: 235-252. Buenos Aires, Imago Mundi.

» Barriera, D. (2016). "La supresión del Cabildo y la creación de los Juzgados de Paz: dimensión provincial de la justicia de equidad en el Litoral rioplatense (Santa Fe, 1833)" en Caselli, E. (coord.); Justicias, agentes y jurisdicciones. De la Monarquía Hispánica a los Estados Nacionales (España y América, siglos XVI-XIX): 427-450. Madrid, FCE/ Red Columnaria.

» Barriera, D. (2017). El alcalde de barrio, de justicia a policía (Río de la Plata, 17701830). Nuevo Mundo Mundos Nuevos [En ligne] Débats. Disponible en Internet: http:// nuevomundo.revues.org/70602. Consultada el: 10 de septiembre de 2017.

" Barriera, D. (2018). “Y en el principio, fue la justicia. Las alcaldías de barrio: visibilización de un desenredo en la cultura jurisdiccional (De justicia a policía y nuevamente a justicia: 1772-1861)" en Barriera, D. (dir.); Justicias situadas: Instituciones, agentes, cultura y espacios (entre el Virreinato rioplatense y la República Argentina, 1776-1864): 129-162. La Plata. Universidad Nacional de La Plata, FaHCE.

» Barriera, D. (2019). Historia y justicia. Cultura, política y sociedad en el Río de la Plata (siglos XVI-XIX). Buenos Aires, Prometeo libros.

》 Bohoslavsky, E. y G. Soprano (edits.) (2010). Un estado con rostro humano. Funcionarios e instituciones estatales en Argentina (desde 1880 hasta la actualidad). Buenos Aires, Prometeo.

" Bonaudo, M. (2005). "Hecho jurídico...hecho político. La conflictiva relación entre poder y justicia en la construcción de la República Posible. Santa Fe, 1856-189o" en Carzolio, M. I. y D. Barriera, D. (comps.); Política, cultura, religión. Del Antiguo Régimen a la formación de los Estados Nacionales. Homenaje a Reina Pastor: 215-240. Rosario, Prohistoria Ediciones.

» Bourdieu, P. (2012). Sur l'État. Cours au Collège de France (1989-1992). Francia, Raisons d'agir/Seuil.

» Bragoni, B. y E. Míguez (2010) (coords.). Un nuevo orden político. Provincias y Estado nacional, 1852-1880. Buenos Aires, Editorial Biblos. 
»Corva, M. A. (2017). La elección popular de los jueces de paz en la provincia de Buenos Aires. Fracaso y conflicto de poderes. Derecho en acción 4. Disponible en Internet: https://revistas.unlp.edu.ar/ReDeA/article/view/3909. Consultada el: 23 de abril de 2020.

»De los Rios, E. (2017a). Gobernar es cobrar. Política fiscal, recaudación impositiva y cultura tributaria. Santa Fe, (Argentina, 1855-1872). Rosario, Prohistoria Ediciones.

» De los Ríos, E. (2017b). Sentar las bases del orden fiscal. Los presupuestos de Santa Fe (Argentina, 1855-1873). Revista Res Gesta 53: 100-122.

»De los Ríos, E. (en prensa). La justicia de paz y las transformaciones en el gobierno de la ciudad (Rosario, 1852-1872). Revista de Indias.

»De los Ríos, E. y C. Piazzi (2012). “Comisarios de campaña en el departamento Rosario: entre ocupaciones públicas e intereses privados (1850-1865)” en Garavaglia, J. C.; Pro Ruiz, J. y E. Zimmermann; Las fuerzas de guerra en la construcción del Estado: América Latina, siglo XIX: 381-412. Rosario, Prohistoria ediciones.

» Di Liscia, M. S. y G. Soprano (2017). “Entre espacios grises y aristas brillantes: la categoría de burocracia estatal y el estudio de los sistemas de administración pública en la Argentina" en Di Liscia, M. y G. Soprano (edits); Burocracias estatales. Problemas, enfoques y estudios de caso en la Argentina (entre fines del siglo XIX y XX): 9-41. Rosario, Prohistoria/ EdUNLPam.

»Echegoyen, S. (1859). “Quien tiene razón grita. Contra los extravíos de la Autoridad pública” en El Litoral. 11 de marzo de 1859.

»Ensinck, O. (1963). Jurisdicción y atribuciones de los jueces de paz (1833-1854). Revista de Historia de Rosario 3: 5-25.

» Garavaglia, J. C. (1999). Poder, conflicto y relaciones sociales, el Río de la Plata (siglos XVIII$X I X)$. Rosario, Homo Sapiens.

» Garavaglia, J. C. (2010). La burocracia en el Río de la Plata. Buenos Aires, 1880-1861. Anuario IEHS 25: 119-144.

" Garavaglia, J. C. (2012). Servir al Estado, servir al poder: la burocracia en el proceso de construcción estatal en América Latina. Almanack 3: 5-26.

» Garavaglia, J. C. (2016). La disputa por la construcción nacional argentina. Buenos Aires, la Confederación y las provincias (1850-1865). Buenos Aires, Prometeo Libros.

» Garavaglia, J. C. y J. Pro Ruiz (eds.) (2013). Latin American Bureaucracy and State Building Process (1780-1860). UK, Cambridge Scholars Publishing.

» Gastellu, S. (2018). “La Justicia de Paz en la ciudad de Buenos Aires. La dimensión territorial de una justicia de proximidad (1821-1854)" en Barriera, D. (dir.); Justicias situadas: Instituciones, agentes, cultura y espacios (entre el Virreinato rioplatense y la República Argentina, 1776-1864): 263-290. La Plata, Universidad Nacional de La Plata, FaHCE.

» Gastellu, S. (2019). Una justicia para el gobierno local: los jueces de paz de la ciudad de Buenos Aires (1821-1826). Revista de Historia del Derecho 58: 83-129.

» Hespanha, A. (1989). Vísperas del Leviatán. Instituciones y poder político (Portugal, siglo XVII). Madrid, Taurus Humanidades.

» Molina, E. (2018). Circuitos comunicacionales, prácticas administrativas y estrategias de gobierno. Subdelegacía de San Martín, Mendoza (Argentina), 1821-1859. Americania, Revista de Estudios Latinoamericanos 7: 63-93.

» Piazzi, C. (2012). “Vínculos sagrados, crímenes de sangre: mundo jurídico, administradores de justicia, imaginarios sociales y protagonistas. Desde la instalación 
de la justicia criminal letrada de 1ํInstancia hasta la sanción del Código Penal (Rosario, Argentina, 1854-1886)". Tesis doctoral. Facultad de Humanidades y Arte, Universidad Nacional de Rosario.

» Piazzi, C. (2017). Administración y materialidad: una etnografía del Juzgado del Crimen del Rosario (Argentina, segunda mitad del siglo XIX). Historia Crítica, 63: 53-74.

» Piazzi, C. y A. Lanteri (2019). La administración pública en la Argentina en perspectiva histórica. Propuestas sobre el quehacer administrativo y las funciones judiciales y legislativas en torno a las décadas de 1850 y 1860 . Revista de Historia Americana y Argentina 54 (1): 241-276.

»Plotkin, M. y E. Zimmermann (comps.) (2012). Los saberes del Estado y Las prácticas del Estado. Política, sociedad y élites estatales en la Argentina del siglo XX. Buenos Aires, Edhasa.

» Registro Oficial (1890). Registro Oficial de la provincia de Santa Fe (ROSF). Santa Fe, Tipografía de la Revolución, 1890.

»Santa Fe ([1858] 1900). Censo de la Provincia, 1858. Registro Estadístico de la Población de la Provincia de Santa Fe (Confederación Argentina), Con sujeción al Censo Oficial levantado en abril de 1858 bajo la dirección de Juan José Gormaz y Carreras. copia manuscrita del original auténtico por Gabriel Carrasco. Buenos Aires, (s/e.).

»Veira, A. ([1815] 2000). El oficinista instruidos o práctica de las oficinas reales. Obra elemental, necesaria á todas las clases de empleados en ellas y útil á las demás del Estado. Madrid, Centro de Estudios Políticos y Constitucionales.

» Yangilevich, M. (2017). Justicia de paz y organización del territorio en la campaña sur de Buenos Aires durante la primera mitad del siglo XIX. Un diálogo con Juan Carlos Garavaglia. Prohistoria 28: 73-94. 